\title{
Editorial
}

\section{Achieving profitable growth through more effective new product launches}

The top managers of most companies today are caught in a vice. They have exhausted most operational efficiencies for growing the bottom line. The only option left is growing the top line, and that isn't easy either. This is the current situation:

- No company can hope to grow much faster than the broad economic growth rate in its markets without a radical strategy.

- In most developed countries, population growth is slowing and most people have their needs met by current product offerings.

- Most of the products on the market are already 'good enough' for target consumers' needs.

- Competition is increasing from new products and brands from countries like China, and from retailers themselves. European retailers like Tesco and Aldi have long had strong brands, but now USA-based retailers like Wal-Mart are further shaking up the marketing world. For example, Wal-Mart's Ol' Roy brand of $\operatorname{dog}$ food has quietly surpassed the long-standing Purina brand as the world's top seller.

- Major retailers are creating new product development teams to rival those of manufacturers.

- As more and more retailers expand, the already high percentage of sales many brands have with these chan- nel partners is likely to reach $50-70$ per cent. This dominance puts the channel partner in the position to essentially tell a brand how to run its business.

- Most marketers know that their best hope for having more power than the channel partner is to win the heart of the consumer through big new product ideas, marketed under brands with a high degree of competitive differentiation and relevance. Yet the development and launch of new products is fraught with legendary failure rates and high anxiety on the part of those responsible. The result is that management seeks growth in low-risk incremental improvements. Ironically, an incremental approach makes it next to impossible to achieve the power marketers say they need to grow profitably in a world where channel partners are so strong. An incremental approach makes it nearly impossible to achieve the consistent, profitable growth needed to please shareholders.

Given these challenging conditions, anyone really serious about achieving profitable growth will have to unlearn old ways of searching for solutions, and learn in their place new approaches. This is the key to the profitable growth everyone seeks, for it is not really new products or their launch tactics that fail, 
but we ourselves who fail to grow in the ways necessary to overcome the challenges of today's marketplace. To succeed in this brave new world, we must resist the temptation to do things as we have done them in the past.

\section{TEMPTATION 1: THE TEMPTATION TO SEE THE FUTURE THROUGH THE LENS OF PAST AND PRESENT}

It is common practice to build a strategic plan for growth by first assessing your current strengths and weaknesses, and opportunities and threats. But designing a future through the lens of your current reality actually sets you up for underachievement from the start. It creates a future that is just a reflection of the present - resulting in 'me too' products, incremental growth and shortterm solutions. We should be looking for just the opposite. This requires framing a new reality. When seen through the lens of this aspirational future, it becomes clear what your real strengths and weaknesses, and opportunities and threats are.

How does one begin to frame a new future with growth potential? Here are five possible ways:

- Start with the ideal in mind: In his early days as Intel president, Andy Grove faced declining profits in a commodity business, so he fired his whole management team, himself included. He then told them, 'You've all been hired as the new team to transform Intel from the ground up'. The rest is history. If you were going to start from scratch, what would your ideal look like? If you could develop a branded value proposition without constraints, what would it be?
How would this manifest itself in a portfolio of products and services?

- Challenge the rules that define your category: To give Amazon.com competitive advantage, its founder Jeff Bezos questioned the convention that said the only way to sell books was in retail stores. Flouting the 'rules' of the tyre category, Michelin emphasised a higher-order emotional benefit of 'keeping your family safe' and gained advantage over tyre brands stressing functional benefits like tread wear.

- Change the category in which you compete: Orange growers in the USA are repositioning their product not as fruit but as 'healthy candy'. By stretching his brand from computers to music players with the iPod, Steve Jobs differentiated Apple from the competition and found a billion dollars of new revenue in only 24 months' time. ${ }^{2}$

- Invent a new category: Howard Schultz invented a new category by launching the Starbucks concept to the US consumer. By launching 'at home dental whitening', Procter \& Gamble created a category and found 10 million users and $\$ 300 \mathrm{~m}$ in sales. ${ }^{3}$

- Frame a different reality: At the time Roberto Goizuetta became CEO of Coca-Cola in the 1980s, the soft drink was a leader in its category, but was spending huge amounts of money trying to defend tenths of a per cent in market share. Goizuetta's brilliance was to point out that the average daily per capita consumption of Coke worldwide was two ounces, while the daily per capita consumption of all liquids was 64 ounces. By harshly 
reframing Coke as an underdog, he opened the eyes of his management team to see the possibility for new innovations and acquisitions across a wide range of categories beyond soft drinks. ${ }^{4}$

To create a vision with growth potential, you might try any or all of these strategies. The important thing is to resist the temptation to frame your future from the point of view of your current reality. Instead, define your current strengths and weaknesses from the point of view of a visionary future. Then the real opportunities and gaps you have to address to achieve profitable growth will be illuminated.

\section{TEMPTATION 2: SEARCH FOR OPPORTUNITIES BASED ON CURRENT PRODUCTS}

It is only rational to say, "We know how to make this, so what more can we do to make money with it?'. From your current products it is easy to deduce line extensions. From current customers it is easy to assume a market for a new product. It is only natural to build on the old, the tangible, the world you know.

But the marketplace is not necessarily rational. University of Chicago behavioural economist Richard Thaler makes it his business to study buying decisions. He notes we are even more irrational than we think. His research shows we will go out of our way to avoid a $\$ 100$ loss but do little to make a $\$ 100$ gain. He says our brains see patterns where none exist. ${ }^{5}$ For example, if a stock goes up for three days, our brains reason it will continue to go up. This is because the human brain did not evolve for the logical assessment of marketplace choice. Evolutionary selection prepared us to make quick, pattern-based, emotional decisions. The latest neurological research has shown that almost all human decision making is emotionally based. It is the emotional coding of a marketer's message that gets the brain to even pay attention to any logical arguments offered.

In addition, we know from much research that what consumers tell us they intend to buy is often not what they actually do buy. They cannot help it, because so much of human decision making is subconsciously driven - by emotions, attitudes, a search for meaning etc.

For marketers, this means that the search for opportunities should focus on how to invent new-to-the-world product lines that deliver the meaning and emotional benefits consumers are searching for. Leading marketers are using several tools to do this:

- Anthropology and ethnography help to assess what problems consumers are dealing with and what solutions they are inventing that could be the basis of new products or services. But because observation alone does not usually reveal why people are behaving as they are, it is important to go further.

- In addition to observation, more marketers are using psychoanalyses to understand consumer motivation and uncover the meaning consumers seek in products and services. This includes considering what Carl Jung called the collective subconscious - the universal and timeless desires hard-wired into all mankind. ${ }^{6}$ Research has shown that brands that align themselves closely with one of these desires achieve a 
greater market value than brands which are less focused on a desire innate to us all. ${ }^{7}$

The lesson is that marketers looking for a fresh and pre-emptive road to profitable growth may find richer opportunities when they begin their quest with what is already in the mind of the consumer, rather than what is in their current product portfolio.

\section{TEMPTATION 3: NEW PRODUCT CONCEPTS LOADED WITH FEATURES AND FUNCTIONALITY}

In today's world, nearly any new product, new feature or new function can be quickly matched by a competitor. The better practice is to conceive a scalable brand platform based on the values, attitudes or universal desires of the consumer.

A 'platform' is a concept based on a singular value proposition. It is a foundation that allows you to deliver something relevant to your customer that is different than competitive choices. A scalable brand platform allows you to build multiple product lines - multiple revenue streams - upon its foundation.

The marketplace is full of great examples. There's Apple's brand platform of creativity, now being leveraged into consumer electronics. There's Virgin, with its brand platform built on the 'rebel' archetype, which it has scaled from an airline to cola to record stores and, now, bridal wear.

Scalable brand platforms are not about features or functionality, but higher-level emotional and social benefits. If you are the first to claim a higher-order benefit, your brand is permitted to 'own' it and command a premium price. Research conducted by Milward Brown for WPP confirms that, 'Brands founded on broader values are more elastic than others easier to extend to new categories, new frames of reference, new usage situations, new products. ${ }^{9}$

\section{TEMPTATION 4: CREATE A TRADITIONAL MARKETING PLAN}

Traditional practice dictates that the drafting of a marketing plan requires sequential detailing of the product strategy, followed by its distribution, pricing and promotional strategies. But this linear tradition is contrary to today's reality, where integration and brand alignment are necessary for scalability, efficiency and profitability. Competitive advantage in today's 'communication age' comes from a single strategy, the holistic nature of which combines all the marketing elements and creates more communication value than the competition has.

One example of such a platform comes from the Sub-Zero brand. A few years ago they launched a refrigerator/freezer in a drawer. It could be installed anywhere in your kitchen, your recreation room or your study. It was the big news story of the international home products trade show where it made its debut. The consumer press covered it over and over for a year. Another example comes from the long-popular Procter \& Gamble snack crisp brand Pringles. The newest Pringles have trivia questions printed right on the crisps. Making the snack an edible game doubles the fun factor and increases distribution potential by allowing Pringles also to be where games are sold. The 'talk value' of their 
concept is generating lots of free publicity and talk value.

Creating a holistic brand platform with a singular strategy essentially means you have built the marketing right into the product. This can come from challenging the conventional rules of the category. It might come from reframing reality for your consumer - like pointing out that oranges are really 'healthy candy'. You could build in an unprecedented degree of relevance and differentiation - like Sub-Zero's refrigerator in a drawer. Or you could combine two formerly separate things like a snack food that is also a game. Big ideas all.

There is an assumption that big ideas like these fail more often than incremental ones. But the riskiness of big ideas may be more in the mind of the marketer than in reality. An Information Resources, Inc. (IRI) study examined all new brands and line extensions introduced over a two-year period across 21 categories of business. It found that big ideas fail at the same rate as incremental ones. ${ }^{9}$ So marketers need not avoid the pursuit of the big idea, for their gain can be far greater than the gain from the incremental ones.

Of course, not everyone can create a breakthrough product or new brand platform with the marketing built right in. For them, the opportunity lies in having communications with the 'buzz' built right in. The recent launch of the Mini Cooper in the USA is a prime example of this principle, as is the 1990 s campaign of the British soft drink brand Tango. In both cases, the brands' marketing communications were so relevant and/or disruptive that their news and word-of-mouth value created a reach and frequency beyond that which you would expect from a typical advertising or publicity effort.

Finally, we come to the ultimate practice we must unlearn.

\section{TEMPTATION 5: THE TEMPTATION TO BLAME OTHERS FOR OUR FAILURES}

It is human nature for all of us to whine about the things we cannot control - like the actions of others yet do little about what we can control - our own behaviour. The single most uncomfortable truth we must face to conceive and launch more profitable new products is accepting that the problem doesn't lie with others - the problem lies with me'.

It is natural to consider it a risk to do things in a new way. But, clearly, failure also comes from continuing to launch new products and growth initiatives in traditional ways as well. So let's take risk and failure 'off the table' as things we must avoid, and let's talk candidly about what the problem really is within us all. It is fear.

It is natural, when we are expected to make a big decision, to feel somewhat afraid. Yet fear distorts the perception of risk. So no matter how minimal the risk felt, fear introduces error into decision making. This is because the fear of what might happen overshadows what probably will. In other words, whenever we allow fear to creep in, we are literally ensuring that we will make bad decisions.

Here are a few recommendations for overcoming the fear that keeps us from new practices that can lead us to profitable growth:

- Redesign new product launch processes away from the intention 
not to make a mistake, and imbue processes with a self-fulfilling intent for success. For example, don't ask what is wrong with an idea. Instead, ask, 'in what way can we make this work?'.

- Realise that while unlearning the old and practising the new we are likely to be worse at our jobs for a while. It is a 'right of passage' - becoming worse in order to become better. Being more afraid before we can become more confident. Accept this, and celebrate your journey to greater mastery.

- Instead of dreading fear, reframe it as a leading indicator of your personal growth, a sign that you are about to demonstrate what we all most admire in legendary business leaders - courage. In your head, change your job title from whatever it is now to 'Chief Courage Officer'. Be famous for your courage. Be famous for building it in others. That will immediately help everyone on the team to make better, bigger decisions, for the right reasons. Foster optimism.

- The only fear you should cultivate is that which research shows is the only one that motivates people to do better new-product work: the fear of brand obsolescence.

- Find a new basis on which to make decisions. Business school models have long taught that decision making must be based on logic and data. But if those practices are so reliable when applied to new product development, why aren't they producing more of the profitable growth and effective launches we seek? The answer is that today's rapidly changing marketplace seldom allows the time for sifting, winnowing or alternative scenario building.

- Today's decision-making model for marketers is, when in doubt, 'go with your gut instinct'. This is not as radical as it may seem. More and more psychologists and behavioural economists now argue that gut instinct tends to be more informed than deductive reasoning, resulting in better, even brilliant decisions. Why is this? Researchers explain that gut decisions are based on implicit learning. Subconscious pattern recognition. Things hard to articulate, but often 'spot on'. Implicit learning of real and valuable knowledge.

While growing the top line has never been harder, anyone serious about achieving profitable growth will find that the new practices necessary to achieve it include these:

- Have the guts to envision new realities.

- Fuel new realities with scalable brand platforms - the meaning of which is so relevant to consumers and the products of which are so differentiated from the competition that their marketing and communication strategies are 'built right in'.

- Take responsibility for the behaviour you yourself engage in that hinders big ideas and prevents new ways of problem solving.

- Have the courage to lead others in an atmosphere free of fear.

\section{Marsha Lindsay President and CEO of Lindsay, Stone \& Briggs}




\section{References}

(1) Morgan, A. (1999) 'Eating The Big Fish: How Challenger Brands Can Compete Against Brand Leaders', John Wiley \& Sons, New York, p. 42.

(2) Markoff, J. (2004) 'Oh yeah, he also sells computers', New York Times, 25th April.

(3) Business Week (2003) 'Innovate or die', 6th October.

(4) Charan, R. and Tichy, N. M. (2000) 'Every Business is a Growth Business: How Your Company Can Prosper Year After Year', Three Rivers Press, CA, pp. 4-5.

(5) Business 2.0 (2002) 'How to think with your gut', November, pp. 99-103.

(6) Jung, C. G. (1959) 'The Archetypes and the
Collective Unconscious', Bollingen Series $\mathrm{XX}$, Princeton University Press, Princeton, NJ, pp. 3-53.

(7) Mark, M. and Pearson, C. S. (2001) 'The Hero and the Outlaw: Building Extraordinary Brands Through the Power of Archetypes', McGraw-Hill, NY, pp. 29-30.

(8) Page, G. and Farr, A. (2000) 'Do you have an elastic brand?', presentation given at the Advertising Research Foundation's Workshops, October.

(9) IRI (2000) 'Beating the odds: Projecting new product success rates', viewed 23rd November, 2003, available at www.infores.com 